\title{
Multicase Study Comparison of Different Types of Flood-Resilient Buildings (Elevated, Amphibious, and Floating) at the Vistula River in Warsaw, Poland
}

\author{
Łukasz Piątek ${ }^{1}$ and Magdalena Wojnowska-Heciak ${ }^{2, *}$ \\ 1 Faculty of Architecture, Warsaw University of Technology, 00-661 Warsaw, Poland; lukasz.piatek@pw.edu.pl \\ 2 Department of Landscape Architecture, Institute of Environmental Engineering, \\ Warsaw University of Life Sciences, 02-787 Warsaw, Poland \\ * Correspondence: magdalena_wojnowska-heciak@sggw.edu.pl; Tel.: +48-662-362-064
}

Received: 5 October 2020; Accepted: 19 November 2020; Published: 21 November 2020

check for updates

\begin{abstract}
The study aims to present, compare, and assess three different types of buildings considered as flood-resilient construction: building on piles (also called static elevation), amphibious building (also called can-float), and floating building in terms of their performance in the context of a semiwild river in a large city. The comparative multiple-case study covers three objects realized between 2014 and 2017 at the Vistula riverbanks in Warsaw, Poland: pile founded Beach Pavilion, amphibious Boulevard Pavilion, and floating Water Tram Terminal. The research was based on the blueprints analysis as well as on on-site observations in the phase of construction and operation and interviews. The general characteristic of the three resilient typologies has been confirmed in the study. The pile building has an almost unlimited range of operation regarding the water level on the cost of a relatively remote location from the river, but during an exceptionally extreme flood, it will be flooded. Floating buildings provide the best visual and physical contact with water, cannot be flooded, and may be relocated but access to them from land is hampered, especially during very low and very high water levels. Amphibious buildings seem to be a compromise of water proximity and reliability of operation in all circumstances. A closer look reveals technical problems with buoyant structures. In the case of the floating terminals, problems with mooring on the semiwild freezing river remain a challenge. The amphibious buildings are still in the phase of implementation, waiting for their first test in natural flooding conditions.
\end{abstract}

Keywords: amphibious buildings; floating buildings; pile buildings; flood-resilient architecture; riverbanks; urban green-blue space design

\section{Introduction}

\subsection{The Relationships of Risk, Vulnerability, and Resilience}

The foundations for risk come from multiple disciplines. The term is broadly used in the insurance industry [1]. Differences in risk definitions between disciplines (public health, psychology, environmental health, occupational health, engineering, sociology, and medicine) are not essential and mainly connected to the usage of terminology. In most cases of risk definitions, probability and severity are both important aspects and often a quantification of risk is desired, whereas risk perception is seen as a subjective appraisal and a cognitive construct [2]. The concept of risk is often undertaken in relation to hazards interacting with social structures [3]. However, the key concepts in modern disaster research except for the hazard and risk cover also vulnerability and resilience [4]. 
Vulnerability, being one of the defining components of disaster risk, has also been applied in various disciplinary research domains including hazard and disaster studies, political ecology, and psychology [5-9]. The concept refers to disasters caused by environmental events: earthquakes [10,11], droughts and famine [12], fire [13], or floods [14-16]. Vulnerability to flood hazard is strongly related to local conditions, and different factors influencing flood events [17] require additional variables to consider in the analysis. The meteorological driver of fluvial flooding is predominantly through precipitation [18]. Coastal flooding can occur due to four physical elements either acting on their own or in combination with each other, i.e., astronomical tide, storm surge, wave effects, and local bathymetric effects [19]. The Vietnamese Mekong Delta is vulnerable to floods resulting from sea-level rise due to climate change [20]. New Orleans, USA, suffers due to its location on delta sediments, global sea-level rise, and hurricane activity [21,22]. In river cities, the vulnerability to flood hazard is related to heavy rainfalls, river regulation, and the process of "sealing" the city with nonpermeable surfaces. The trend of mitigating the risk of damage is visible in initiatives not only of restoring the natural riverbed to increase the volume capacity of the riverbed but also by using technologies that adapt new development to the changing water levels.

The concept of resilience covers the philosophy that, as a society, we should learn to live with floods and manage flood risk and not seek to avoid it [23-25]. The resilience may be understood in terms of technological aspects like new inventive building components, materials, or solutions that consider interactions between materials $[26,27]$ or socioeconomic aspects, i.e., including climate change scenarios with long-term land use modeling and flood risk analysis to generate maps and time series of expected annual damages [28-30]. Due to a wide range of issues covered by the term resilience, there are many metrics of assessment of flood resilience [31]. Most of the frameworks to measure flood resilience focus on the relationship between probability and (direct) impact of flooding (engineering resilience) and factors that attribute to resilience such as economic resources, assets and skills, information and knowledge, support and supportive networks, and access to services (socioecological resilience) [32].

\subsection{Floods in Europe}

Considering climate change consequences, the vulnerability of the urban areas to floods seems to be a challenge to many municipalities [33]. According to the analysis based on the European Flood Database showing trends in mean annual river flood discharge in medium and large catchments in Europe over the period 1960-2010 [34], climate change has increased river floods in northwestern parts of central Europe due to increasing autumn and winter rainfall and decreased river floods in southern and northeastern Europe by decreasing precipitation and increasing evaporation and by decreasing snow cover and snowmelt, respectively [35-37]. Another more recent analysis suggests that the number of very severe flood events in Europe increased over the period 1985-2016, but with large interannual variability $[38,39]$.

\subsection{Flood Resilient Strategies}

Different circumstances of the flood events necessitate the use of different resilience strategies on an urban and regional scale. In case of the river floods, despite the national strategies like Room for the River [40] in the Netherlands or Making Space for water in Great Britain [41], which mitigate the problem of river floods [42], there are architectural solutions that enable building in harmony with river ecosystem [43-45].

Building strategies for flood-prone areas (Table 1) are based on two opposite concepts, i.e., avoiding and resisting. According to the first approach, the structure is separated from floodwater. On the urban scale, this is done by protecting the specific area with dikes and flood barriers, while in the case of a single building, water avoidance means elevating it to the safe height above the expected flood level. An elevated building can be set directly on a sufficiently high shore (waterside/waterfront building), artificial mounds (terp house), embankments (dike house), or on supports in the form of slender 
posts (stilt house) or pillars (pile house) $[46,47]$. Being the most universal design concept, overwater structures may be located both on land and in water basins. Except for their support structure they do not require any special materials and construction techniques.

Table 1. The comparison of flood-resilient architecture typologies (" $\mathrm{X}$ " indicates the lack of adequate type).

\begin{tabular}{cc}
\hline (Barker and Coutts, 2015) & (Nillesen and Singelenberg, 2011) \\
\hline & Dike house \\
Elevated building & Terp house \\
X & Pile house \\
Dry-proof building & Waterside house \\
Wet-proof building & $X$ \\
Can-float (amphibious) building & Amphibious house \\
Floating building & Floating dwelling \\
\hline Source: processed by the authors based on [46,47].
\end{tabular}

In the opposite concept of flood resistance, buildings are not protected from contact with water. Instead, they are designed and built to sustain a certain direct exposure to floodwater without damage. Two strategies can be found here, i.e., "dry-proofing" that focuses on creating a watertight external envelope of the building and keeping the inside intact, while "wet-proofing" that allows water to penetrate the inside but ensures quick and cost-effective recovery [46].

A separate group of water-related structures that join two of the abovementioned strategies comprises buildings capable to float due to their buoyancy. When floating permanently, located on the water and secured in place with mooring or anchoring systems, such structures are called "floating buildings" (or, nowadays less often, "houseboats"). To some extent, they are mobile, although this is limited by the number of resources required to transport and secure them in the new location. Another concept of buoyant structures are "amphibious buildings" or "can-float buildings." These are buildings located on flood-prone land plots, connected functionally to the infrastructure and inscribed in the landscape as traditional architecture, but floating during the flood event. These two concepts do not differ significantly in terms of their structure, i.e., they consist of a watertight base in the form of pontoon or hull, which follows the idea of resisting direct water contact, and the superstructure usually built in an ordinary way placed on the top of it, what resembles the strategy of avoidance. The most significant feature of floating and amphibious buildings is their ability to maintain a fixed height in relation not to the land but the water surface.

\subsection{Research Purpose}

The practical postoccupancy assessment of different types of flood-resilient buildings is difficult due to the fact that direct comparison of them in the same but yet natural conditions is challenging. Designers usually decide on implementing only one specific type of flood-resilient structure in the area of development. Therefore, in the analytical research on comparing different types of buildings realized in different locations, there are numerous and substantial external factors that have to be filtered out, with the flood characteristics being the most important one. Moreover, not all of the types presented in Table 1 are equally popular. Especially, the amphibious buildings are very rare and, as a result, hardly available for research.

The local authorities in Poland have just started to implement the living-with-water approach in public developments. Nevertheless, in the course of the revitalization of the riverbanks at the beginning of the 21st century, Warsaw became one of the largest clusters of amphibious architecture in the world. With floating and pile buildings complementing the riverbank landscape, Warsaw can be considered a unique research field laboratory of flood-resilient architecture and urban green-blue space design. 
In this paper, we take the advantage of the opportunity for the direct comparison and assessment of three different types of flood-resilient buildings located in the same context of Warsaw, where the seminatural character of the Vistula river confronted with the urban pressure of the capital city results in various architectural efforts to create a flood-resilient built environment in harmony with the river's life cycle. We believe that the research on strategies to adapt to the river life cycle may much broader application and relevance to a wider spectrum of population than the development of the riverbanks in Warsaw.

\section{Materials and Methods}

The paper focuses on the design approach [48] with a theoretical replication multiple-case method [49] being applied to the unique setting of significant research potential characterized by (1) three cases realized in a similar time (2014-2017) and place, similar in sizes and functions but using different flood-resilient strategies, (2) rare amphibious buildings being one of the cases, and (3) semiwild river with very variable water levels and flows passing through an urbanized area.

Three cases studied in this paper are (1) Beach Pavilion, a service building on piles erected on the semiwild east riverbank, (2) Boulevard Pavilion, one of eight amphibious mixed-use buildings located on the periodically inundated boulevard on the west channelized riverbank, and (3) Floating Water Tram Terminal, one of the four floating buildings mooring from spring to autumn along the west bank (Table 2). They all have many common features, such as small size, public use, investor, and locations within the range of Vistula waters. However, they differ significantly in flood resilience methods they foster. Therefore, the cases are purposive samples selected to describe the new type of development, capable of resisting the rapid inundation as well as operating during low water levels. Moreover, these are paradigmatic critical cases that are central to the theoretical purpose of the investigation and express the different types of amphibious flood-resilient buildings [50].

Table 2. Projects comparison.

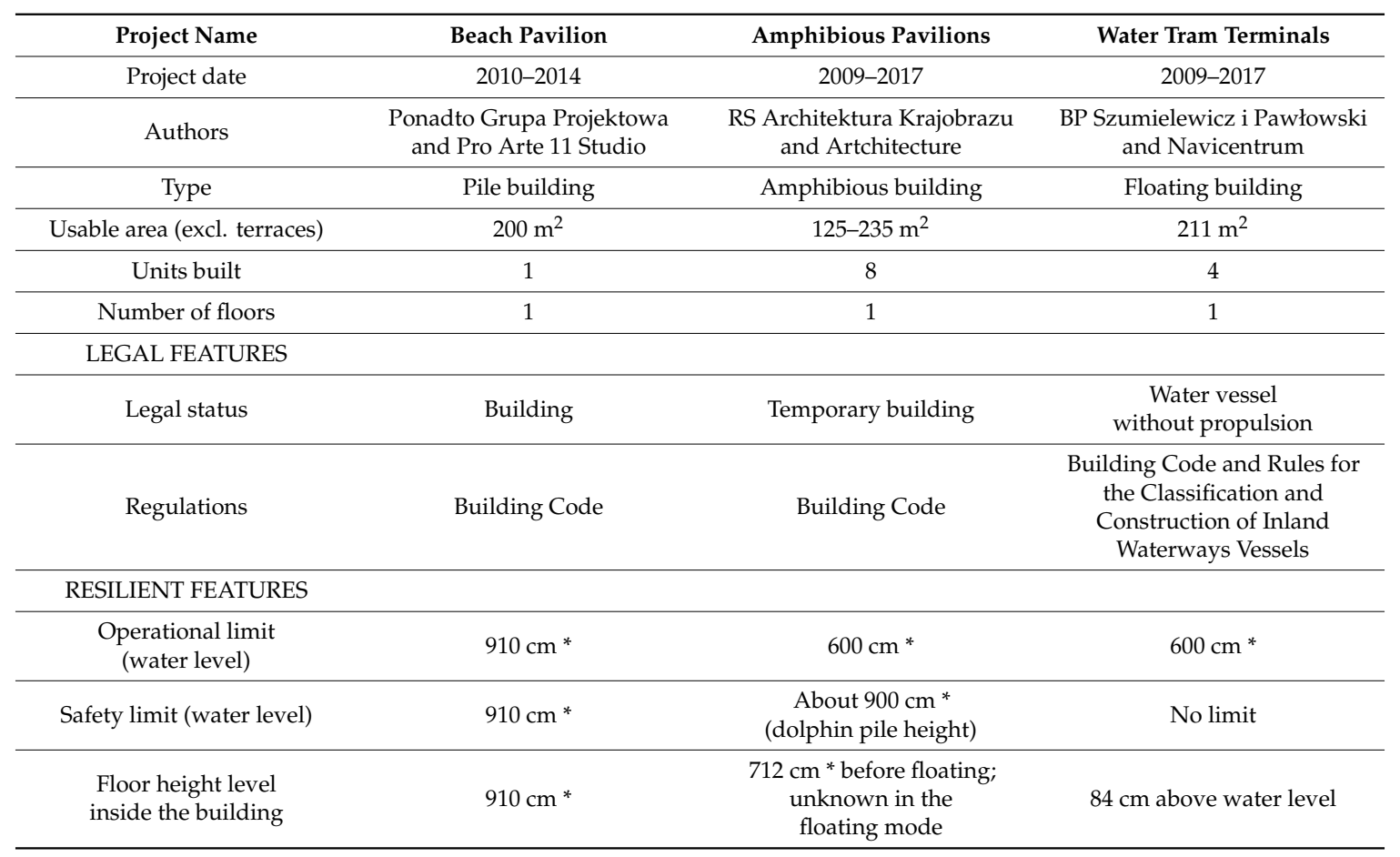


Table 2. Cont.

\begin{tabular}{cccc}
\hline Project Name & Beach Pavilion & Amphibious Pavilions & Water Tram Terminals \\
\hline FUNCTIONAL CONDITIONS & $\begin{array}{c}\text { Very good from the } \\
\text { escarpment; limited from the } \\
\text { beach due to the } \\
\text { height difference }\end{array}$ & $\begin{array}{c}\text { Moderate (hampered by the } \\
\text { height of the } \\
\text { floating base) }\end{array}$ & $\begin{array}{c}\text { Limited (only two gangways } \\
\text { with inclination dependent on } \\
\text { water level) }\end{array}$ \\
\hline Visual contact with water & $\begin{array}{c}\text { Poor (except for } \\
\text { flood events) }\end{array}$ & Good & Very good \\
\hline Access from water & No access & No access & Very good \\
\hline Redeployability & No & No & Yes
\end{tabular}

* All levels referred to gauging station Warszawa Bulwary. Source: processed by the authors.

The multiple-case study comparison was structured to cover elements that impact the coexistence of the building and the river and, as a result, the flood risk, such as location, structure, program, aesthetics, and the resilient concept.

The main research techniques implemented in the study are analysis of the blueprints and on-site observations in the phase of construction and operation of the buildings supplemented with unstructured interviews with designers and operators. Several visits during different stages of the river were conducted to verify the adopted flood resilient solutions [51].

\section{The Research Context}

The Vistula riverbanks attract Warsaw residents longing for recreation in the natural environment. This activity requires certain services, from sanitation to catering, to be provided at the waterfront and creates development pressure on the flood-prone biodiverse area. This infrastructure has to be practical, cost-effective, and resilient. Therefore, the research problem may be seen in the context of the implementation of the new infrastructure that is necessary to allow for safe and comfortable use of public riverbanks and preservation of the semiwild character of the river at the same time. Considering the forthcoming climate changes, this problem seems to gain on significance, as the number of people affected by local flash floods and river floods, rises [33]. Therefore, the flood-resilient buildings might turn out to be useful solutions for further development not only at the riverbanks but also in other urban areas.

\subsection{The Vistula River in Warsaw}

As the majority of watercourses in Europe have been regulated and now the renaturalization of urbanized sections of the large channeled rivers remains the main issue in the West, there are still few semiwild, party channelized rivers in Central-East Europe [52]. One of them is the Vistula-the largest Polish river and the second largest river in the Baltic Sea drainage area. The Vistula catchment covers $55 \%$ of Poland and is inhabited by about 21 million people [53]. The only comparable river in Europe based on the average catchment size, the river length, and the river type is the Loire in France. The unique character of the Vistula, rare among rivers passing through the European capital cities [52,54,55], is especially evident in Warsaw. On its $31 \mathrm{~km}$-long stretch crossing 1.7 million-inhabitant agglomeration, the Vistula has preserved natural features of a braided river like numerous islands, oxbow lakes and side channels that host water-dependent ecosystem. The natural environment of riparian forests on the unurbanized east bank is characterized by three stripes of vegetation, i.e., grassland meadow, wicker and willow patches, and riparian forest communities (Figures 1 and 2). Despite the environmental value, this unusual situation of a semiwild river in the city center has a number of drawbacks. High water level fluctuations affect the complexity of bridges, riverbank infrastructure, and water intake structures. Both the high and low water levels temporarily suspend water transport and the use of ports [56]. This flood risk together with the necessity of protection of the environmental values lead to building restrictions in the area between the dikes. 


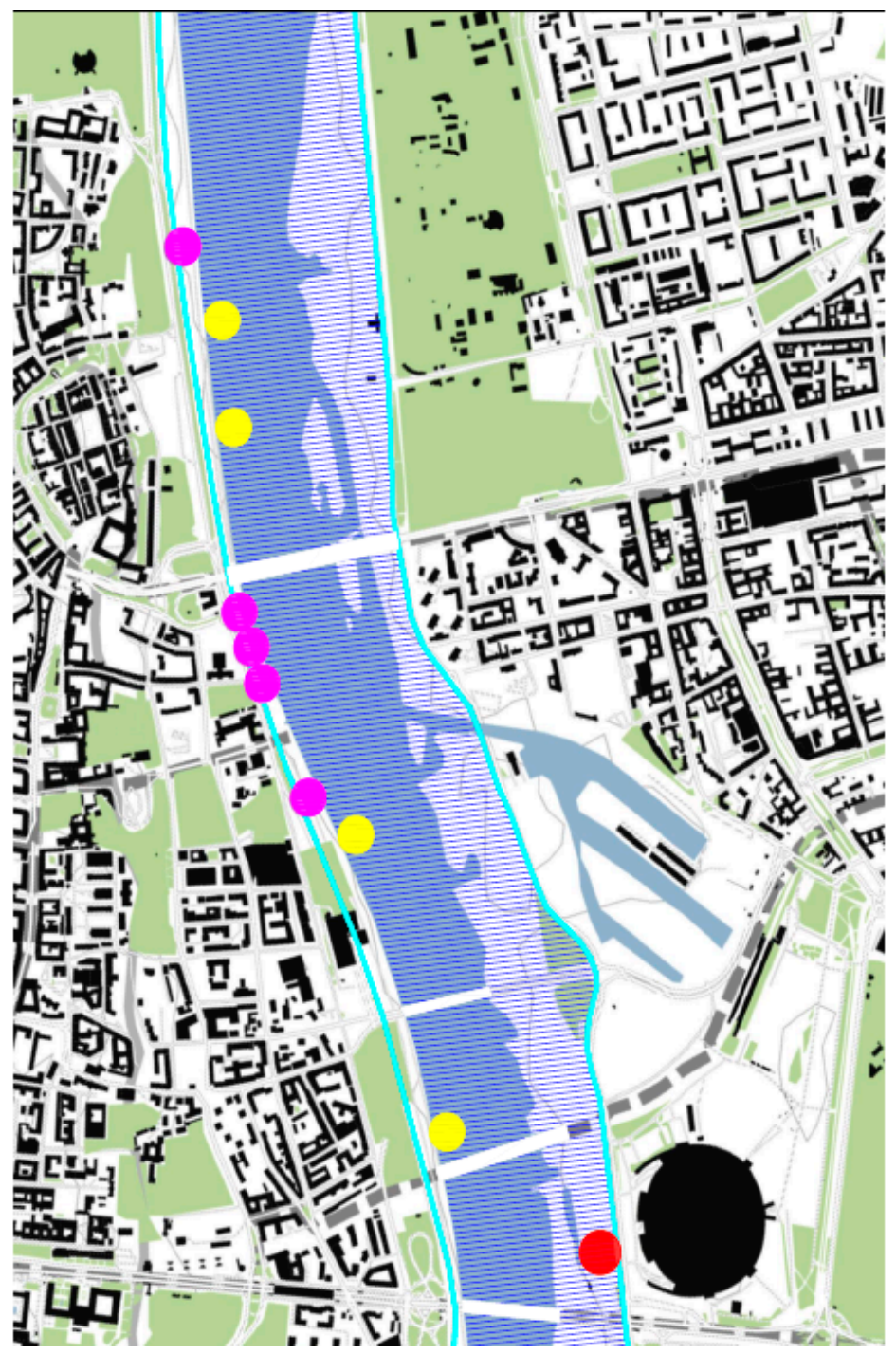

Figure 1. Location of flood resilient buildings examined in the study: Water Tram Terminals (yellow dots), Beach pavilion (red dot), and amphibious pavilions (purple dots). Natura 2000 site marked by navy blue hatching. Dikes marked in cyan lines (Source: processed by the authors, based on [57]).

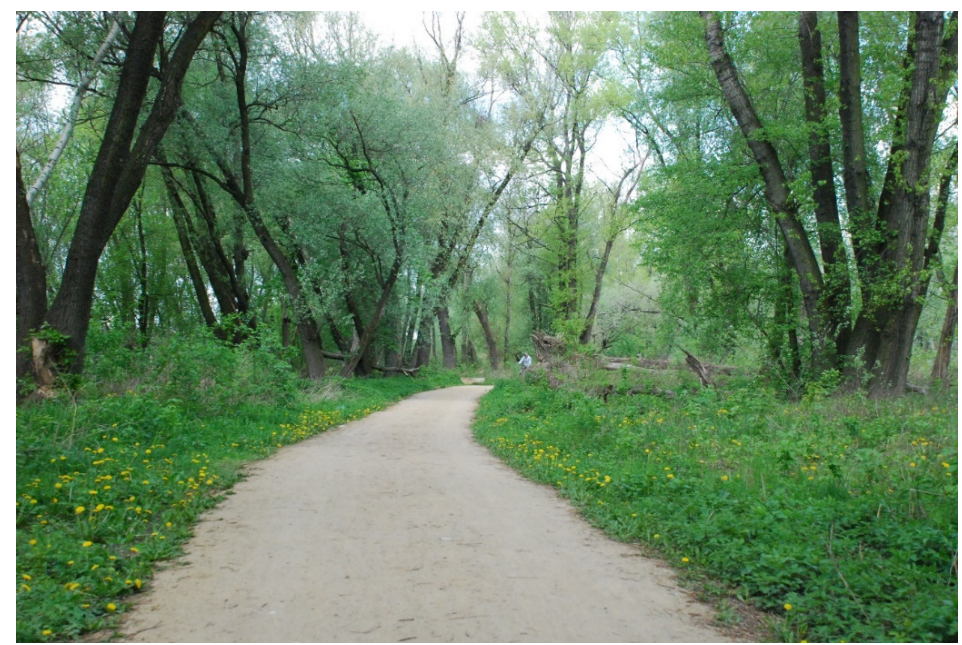

Figure 2. Riparian forest at the right Vistula riverbank (photo taken by Magdalena Wojnowska-Heciak, May 2019). 


\subsection{Floods and Drouths}

Vistula River water levels measured between 1813 and 2000 show the decrease over years [58-60]. Nevertheless, floods remain a serious threat. The high variability of the flow is caused mainly by the rain-snow regime. There are two periods of flooding, i.e., longer and more intense after snow melting in spring and shorter, usually milder, after heavy rainfall in summer [56]. The midstream of the Vistula is dominated by melting floods (often with ice). Snowmelt-induced floods have constituted $64 \%$ of all floods on the Middle Vistula [59,61].

Vistula water levels in Warsaw are measured at the gauging station Warszawa Bulwary, which has a base value of $0 \mathrm{~cm}$ set at the height of $75.99 \mathrm{~m}$ above mean sea level and two values being used to show the high risk of flood damage: warning stage of $600 \mathrm{~cm}$ and emergency stage of $650 \mathrm{~cm}$. The highest water level recorded in history, $863 \mathrm{~cm}$, was caused by heavy precipitation in 1844 . Lower districts of Warsaw and suburban areas from Wilanów to Kazuń were flooded then [62].

The last significant culmination wave with the water level reaching $520 \mathrm{~cm}$ reached Warsaw on 27 May 2019. The boulevards at the left riverbank were closed but the water did not reach the upper terrace, hence the buildings located there were not affected by the water. On the contrary, the right semiwild riverbank has been covered by the water (trash bins, toilets, fireplace grates, and sun leisure, and other movable elements were removed from the beaches). Later in 2019, after a period of heatwave and drought, on June 5th, the water level dropped at the level of $59 \mathrm{~cm}$, which allowed to cross the river almost on-foot [63].

This data shows that despite the long-term decrease in the mean water level in the river the risk of flooding is still present and affects the development of Warsaw riverbanks. Moreover, the seminatural character of the river requires the infrastructure to cope with extreme (very high and very low) water levels during the year. To operate optimally, buildings should be as close as possible to the water, which retreats during the long dry season and resist culmination waves or even a flood every year.

\subsection{Building Restrictions}

The second limitation for riverbanks development in Warsaw comes from the natural values of the semiwild river riparian zone. The WWF report states that the changes in the water levels are responsible for the biological diversity of aquatic ecosystems [35,64]. In return, forests adjacent to the reservoirs are crucial for preserving these waters in good ecological status [65]. Therefore, the Vistula Valley in Warsaw is a part of the Natura 2000 area of the "Central Valley of the Vistula River" (area code PLB140004). It covers the river itself and riparian forest at the east riverbank, but not the west bank with concrete embankment and boulevard along the densely urbanized city center (Figure 1). The development that can significantly influence the protected site is prohibited in this area and, according to the EU Habitats Directive, the management of the area cannot deteriorate habitat and decline the species population. Two examples out of our case studies, Beach Pavilion and Water Tram Floating Terminal, were located within the Natura 2000 area, and had to undergo these limitations.

\section{Multiple-Case Study}

\subsection{Beach Pavilion}

Beach Pavilion design is the result of the architectural competition for a beach facility with a public restroom organized by Sanitec Koło company in 2010. Three years later, local authorities decided to implement the winning project of a one-story pile structure at the sandy Vistula bank.

Site: The project, located near two landmarks in the city, i.e., the Poniatowski Bridge and the National Stadium, takes the advantage of the walkable character of the riverside forests often visited by pedestrians, cyclists, and beach users. It is located in the Natura 2000 area (Figures 1 and 2). The pavilion serves as a link between the Vistula beach and the sidewalk going $2.7 \mathrm{~m}$ higher on the top of the dike. At the same time, it blends with the terrain topography without eliminating the surrounding trees. 
From the land-side, the Pavilion seems to be a typical building. However, the water-side facade reveals its characteristics of an elevated structure.

Program: The layout of the Beach Pavilion is a composition of two volumes linked together in a system of ramps, stairs, and viewing terraces. A mixed-use program comprises showers with changing rooms that operate seasonally in the southern wing at the ground level (below the main floor) and toilets located above them on the street level. The space of the second wing was arranged into a cafe with glazed walls and a terrace.

Aesthetics: The facade made of large-format HPL panels and balustrades in black painted galvanized steel together with the wooden wall cladding and floorboards in Siberian larch creates a modest image that does not disturb the natural atmosphere of the riparian forest. The sliding glass panels allow for direct contact with the site and viewing the river.

Structure: The Pavilion has a reinforced concrete structure set on piles. The most complex and mobile element is the ramp that facilities access to the beach. The ramp consists of two parts: fixed and dismountable [66].

Resilient concept: pile building/wetproof building. Because of the flood risk, the building was raised above the beach (Figures 3 and 4). The main access on the street level allows for the overwater part of the pavilion to be operated even during the extreme floods. Changing rooms, showers, and a bar on the beach level can be removed in case of flooding. The remaining infrastructure is wet-proof. The lower part of the ramp can be lifted with a mobile crane, what was proved to work perfectly during the summer flood in 2014. Nevertheless, fitting the structure with buoyant stairs to avoid the necessity of using a crane to secure it could make the building even more amphibious.

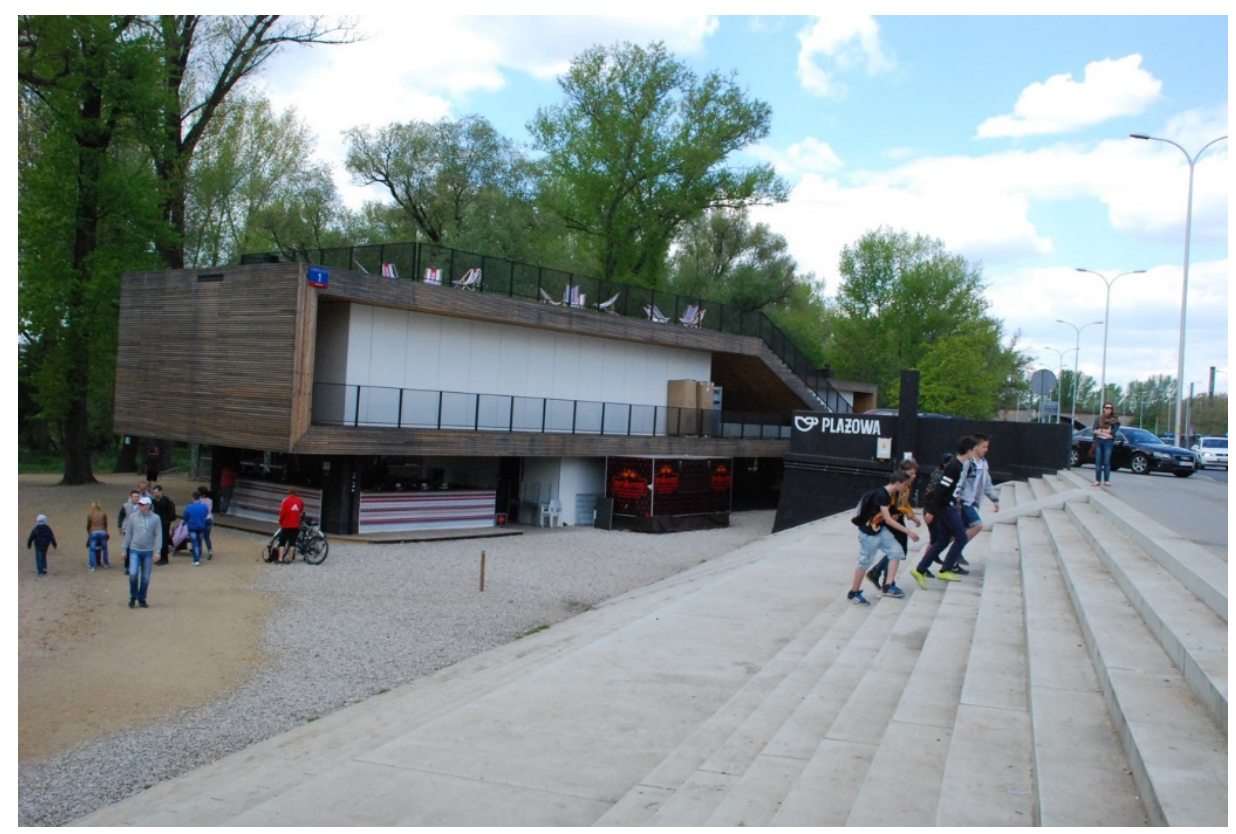

Figure 3. Beach Pavilion view from the Wał Miedzeszyński street (Source: photo taken by Magdalena Wojnowska-Heciak, May 2015).

Assessment: Elevating the building above the flood level is a successful strategy in this location. The building can operate despite the water conditions and is well connected to the city structure. Unfortunately, this system of construction does not provide a close relation to the river. Throughout most of the year, during the average condition, water is far away (c.a. $100 \mathrm{~m}$ ) from the building and the beach cannot be fully serviced. 


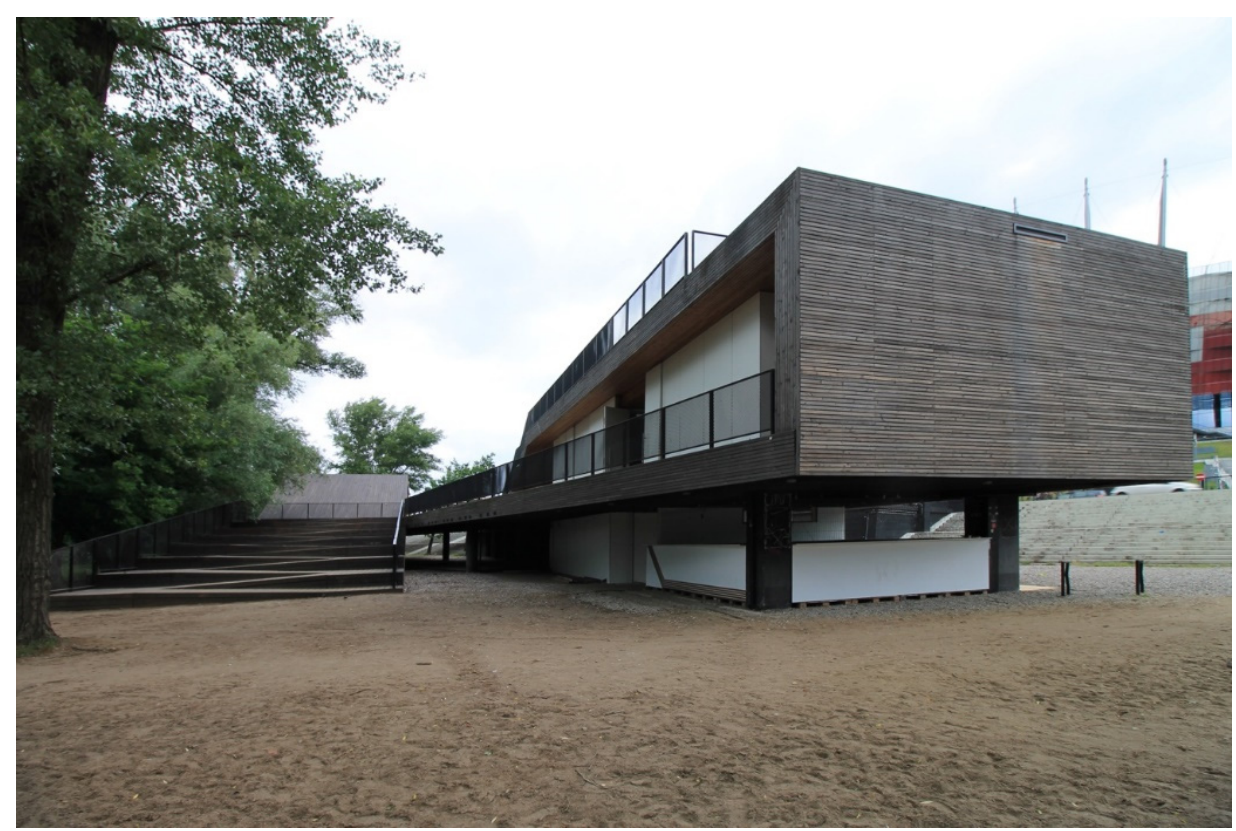

Figure 4. Beach Pavilion seen from the beach. Articulated ramp visible on the left-hand side. (Source: photo taken by Łukasz Piątek in June 2017).

\subsection{Amphibious Boulevard Pavilions}

Two other designs in the study, Amphibious Boulevard Pavilions and Floating Water Tram Terminals, were the winning entries in the competition for the revitalization of the left bank Vistula Boulevard in 2009. In 2017, eight prefabricated amphibious buildings having the same structure and appearance but different areas and functions were finished. Due to their location on the land lot and foundations not permanently connected with the soil, according to the Polish building code, they are classified as temporary buildings, which implies all regular building restrictions to be met.

Site: The new boulevard, encompassing a promenade and a bike path, is squeezed between the riverbank and six-lane street. It varies from 25 to $45 \mathrm{~m}$ in width, which leaves not much space for the buildings. All pavilions are then set parallel to the riverbank, spread irregularly along the 2-km-long waterfront terrace that is positioned $4.5 \mathrm{~m}$ above the mean water level but still $3 \mathrm{~m}$ below the street level. The location of the pavilions is beyond Natura 2000 area (Figure 1). This terrace is prone to rapid inundation with fast-flowing floodwaters carrying debris, which is why traditional buildings could not be used here. First, these facilities were supposed to be light modular buildings capable of being demounted and carried away from the flood zone within 3 days from the flood warning. During the design phase, the idea turned out not to be feasible due to the necessary logistic effort. The amphibious concept has been introduced and implemented instead.

Program: Being the only buildings on the boulevard, the Pavilions have basic public functions. They consist of two or three independent parts including lavatories, bars, tourist information, and exhibition galleries. They are all one-story buildings of internal areas varying from 125 to 235 sq. m [67].

Aesthetics: The pavilions, designed as a part of a larger landscape project, rather blend into the surrounding than distinguish from it. Their unified modest modern look created by wooden vertical shutters covering dark-grey steel structure goes along with the style of the boulevard furnishing like pergolas, lanterns, and other minor equipment. Unfortunately, this unpretentious appearance is disrupted with relatively large floating bases, which were not lowered into pits below the promenade but left on the surface. As a result, the buildings are raised above the boulevard by $1.2 \mathrm{~m}$ and may be accessed via stairs or ramps, which make the pavilions' bases even larger. 
Structure: All buildings have the same structure based on the module sized $2.5 \mathrm{~m} \times 7.0 \mathrm{~m}$. The individual module consists of a $0.7 \mathrm{~m}$-high steel watertight pontoon and a $3 \mathrm{~m}$-high steel frame. There are 7-15 modules bolted together to shape a pavilion, which sits on a concrete foundation slab. Sandwich panels and glass are used for the walls.

Resilient concept: Amphibious. Flood resistance of the pavilions is based on the amphibious concept, according to which the structures will be raised by the floodwater. Buoyancy force counterbalancing the gravity will be generated by watertight steel compartments in the buildings' bases. While floating, each pavilion will be held in place by four clamps sliding along the dolphin piles driven into the boulevard next to the building's corners. This will allow for vertical movement and prevent horizontal movement of the structure (Figures 5-7).

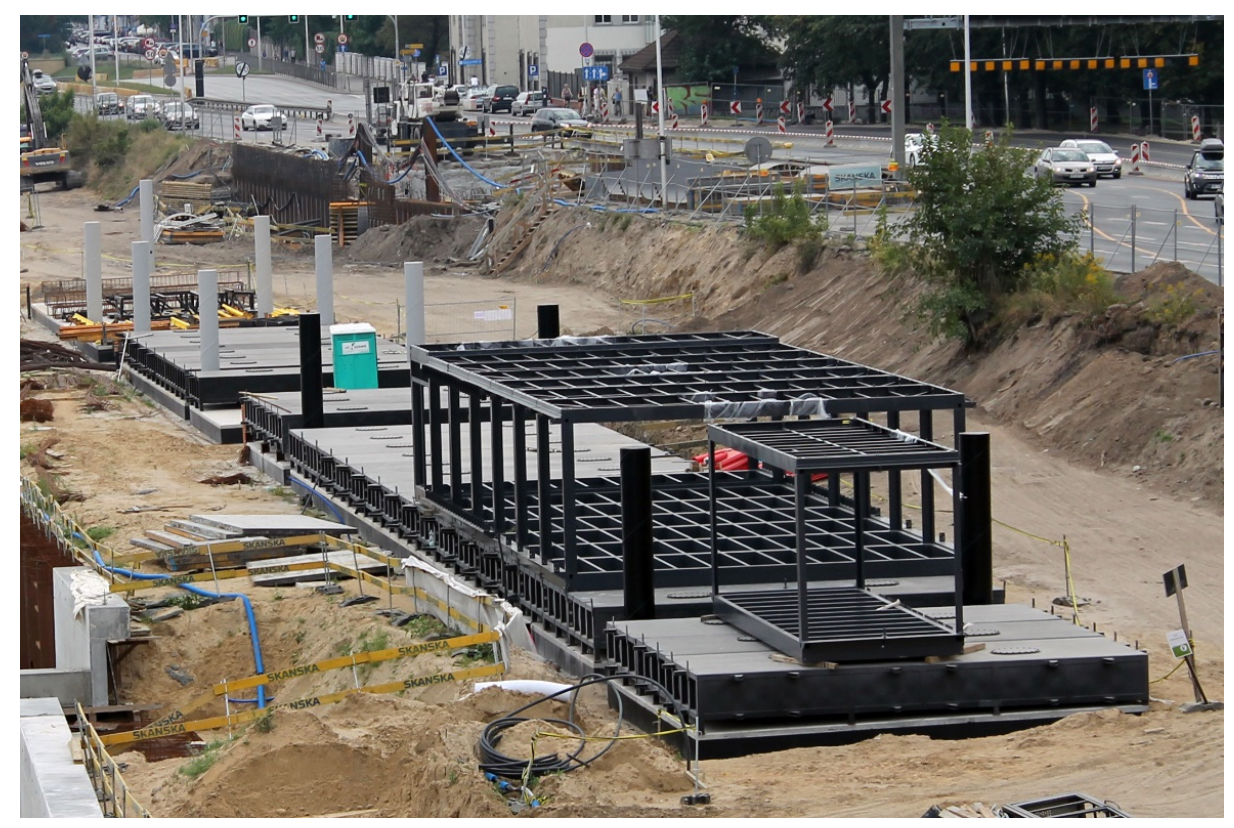

Figure 5. Construction phase of the amphibious pavilion. Dolphin piles, floating bases and the container-like structure visible (Source: photo taken by Łukasz Piatek in June 2017).

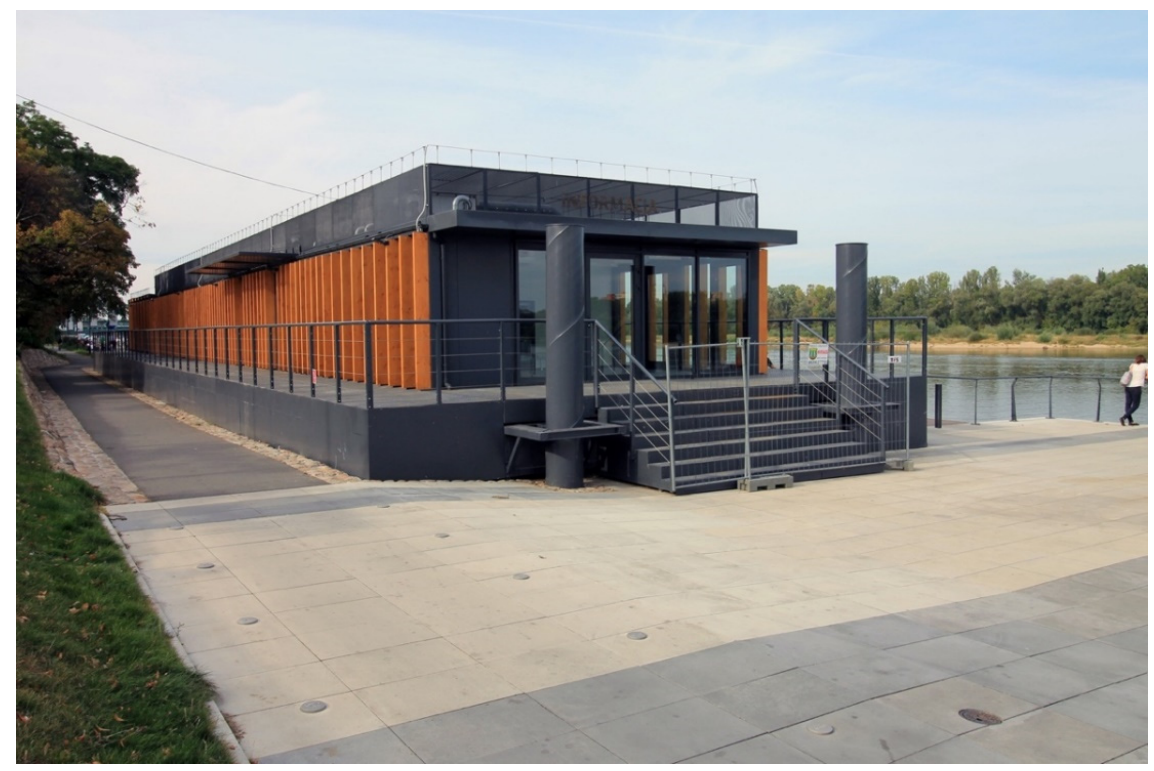

Figure 6. Amphibious Boulevard Pavilion seen from the boulevard (Source: photo taken by Łukasz Piątek in September 2016). 


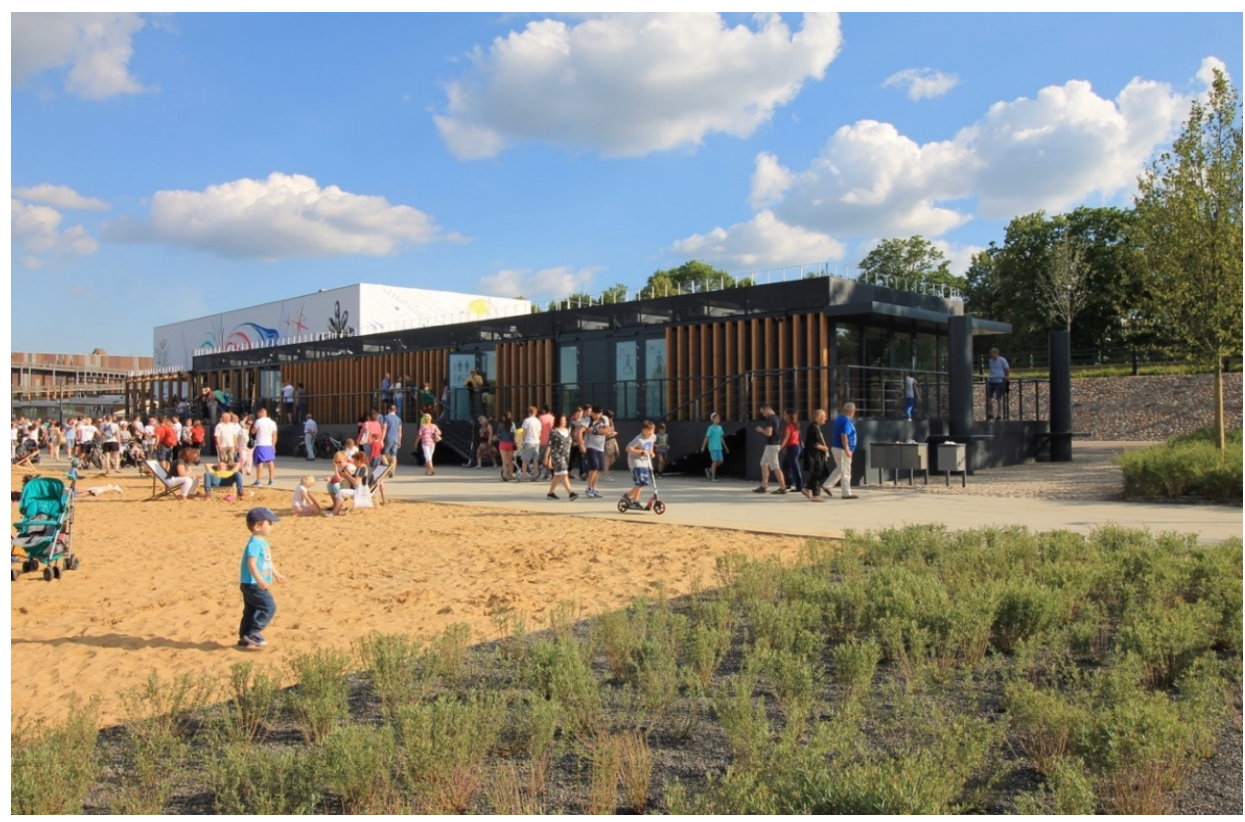

Figure 7. Amphibious Boulevard Pavilion (Source: photo taken by Łukasz Piątek in June 2017).

The pavilion has to be prepared for flooding by disconnecting the utilities. During the flood, the movements of the pavilions should be monitored. Special attention has to be paid to removing debris and other objects from below the floats, to avoid the skew settling or structural breakdown. In the case of the anticipation of a larger flood, the buildings can be still disassembled and relocated beyond the flood zone by heavy machines.

Assessment: Since the first pavilion was finished in 2018, there was no flood in Warsaw that could examine the structure working in the floating mode. To assess (at least partially) the performance of such unusual structure, a real experiment of building buoyancy has to be conducted. It would confirm the proper mass and displacement distribution as well as the real draft of the structure in the floating mode. Such a test can be made with movable flood barriers. Other uncertain technical issues, like the protection from debris carried with the river, may be examined only during the real flood. Despite these problems, the idea of introducing such public buildings in the flood zone proved to be right. The high demand for new structures placed closer to the river is visible in the public visiting the pavilions every sunny weekend.

\subsection{Water Tram Terminals}

The revitalization program for the left-bank introduced one more type of flood-resilient structure: a floating building. Four units of this type were designed to serve as Water Tram Terminals. The selection of the floating solution was addressing two problems at the same time. The first one was improving the mooring conditions for ships, which could hardly use the wharf with water level fluctuation reaching annually $5.5 \mathrm{~m}$. The basic function of the passenger terminal is providing easy, fast and safe access from land via the terminal to the ferry. Therefore, floating structure with a stable relation to water surface was a perfect solution. The second advantage of the floating building for this location was its legal status-being categorized as an inland ship, and not a building, thus, it did not undergo the landscape protection regulations, which ban new buildings in the zone around the historical site of the Royal Castle.

The Floating Terminals, built in Warsaw in 2017, are hybrids between ships and buildings in many aspects. They were designed in civil and naval offices, built by a shipyard and building contractors, and were used in fixed locations despite their status of a vessel [68]. The hull design follows the regulations of the Polish Register of Shipping and the superstructure design follows the Polish building code. The structure as a whole meets Inland Waterways Navigation Rules (Figure 8). 


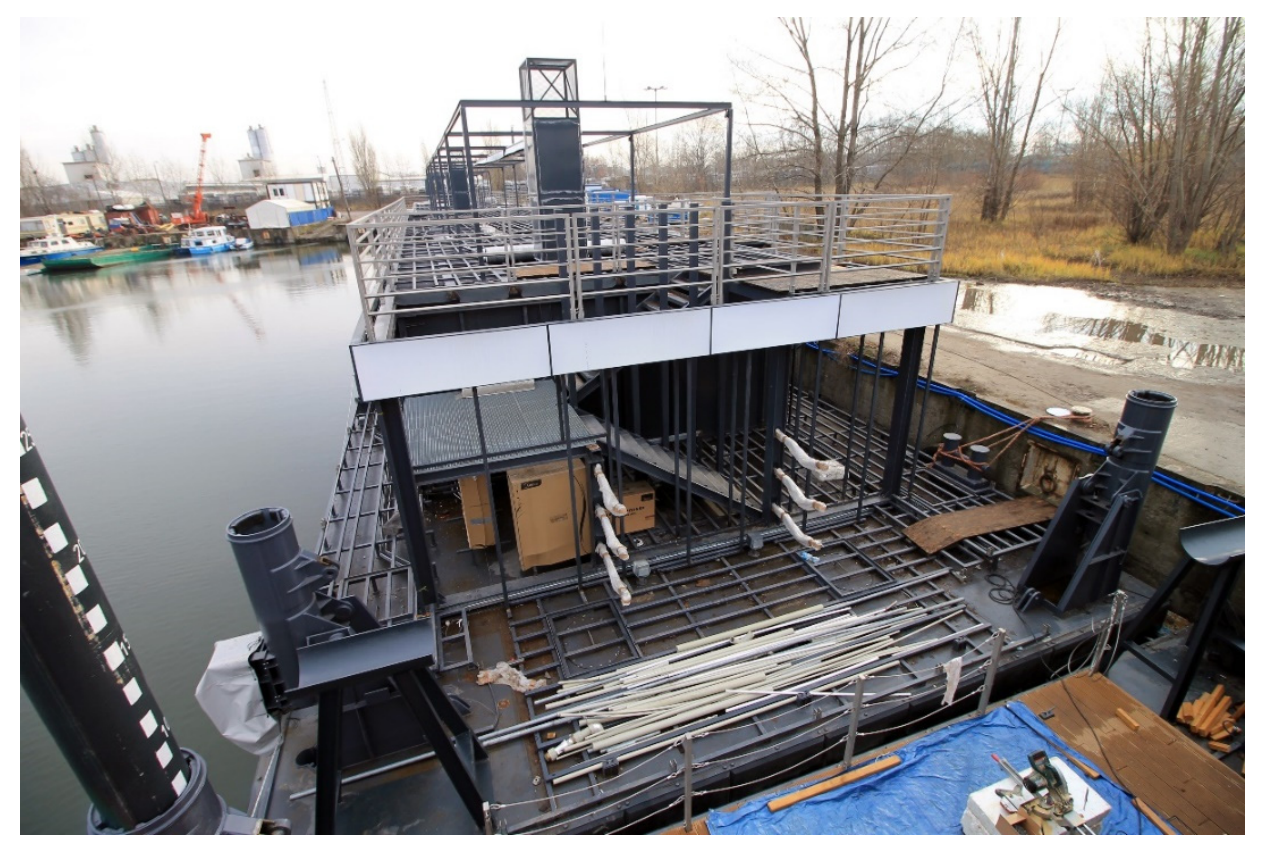

Figure 8. Construction phase of the floating terminals. Two sleeves for the stopping piles visible in the corners of the platform (Source: photo taken by Łukasz Piatek in November 2016).

Site: The Floating Terminals are located in three areas along the revitalized waterfront: two of them in the northern part of the new boulevard, along the Old Town, one in the central part, and one in the southern end, in the area of the metro station. The riverbed is covered by Natura 2000 site's protection (Figure 1).

Program: Despite minor differences, all buildings are identical multifunctional structures encompassing passenger waiting room, ticket office, toilets, and the restaurant on the water level and a roof terrace with a bar on the top. One of them will also serve as a marina with berths and utilities for private yachts. The number of people onboard has been limited to 120 persons per unit, including 2 crew members. Floating bases are $40.0 \mathrm{~m} \times 10.7 \mathrm{~m} \times 1.1 \mathrm{~m}$ to fit in the nearby water lock in the Port of Żerań.

Aesthetics: In terms of their appearance, the buildings do not resemble ships at all. With one-story boxy superstructures on the top of rectangular pontoons, they could be confused with fixed bottom-based structures. The facades are composed horizontally with long illuminated signboards running around the building and level wooden battens. This distinguishes the Terminals from the amphibious pavilions of a similar size standing on a promenade above them. The materials and colors match those on the boulevard and inscribe the building in the waterfront surroundings.

Structure: The structure of the terminals consists of two parts. The bottom part is a steel cuboid hull and has ship-like longitudinal and transverse bulkheads dividing it into 12 dry compartments. The top part is a steel frame welded to the pontoon and finished with sandwich wall panels and glass (Figure 8). Water, electricity, and sewage lines run from the land utility connections on the boulevard to the building through flexible hoses under the gangway. The Terminals are fitted with electric-powered heating and ventilation.

Resilient concept: Water Tram Terminals are floating buildings (Figures 9 and 10). Despite the floating nature of the studied buildings, which can be considered flood-proof, many problems related to mooring and access had to be solved to achieve an acceptable level of safety. The terminals are being exploited in unfavorable natural water conditions for floating structures: strong current, high fluctuations of water level, and winter icing. These conditions are considered by the local water management company Wody Polskie (WP) when issuing a permit for mooring at the waterfront. According to WP, there is no possibility of mooring in that area during the winter season due to ice 
floe, so the terminals have to be relocated before the Vistula shipping route is closed. Not to block the ice flow, driving the mooring dolphin piles into the riverbed were not allowed either, which became a serious problem for the structure with the box-shaped floating system that generates a significant resistance in the current.

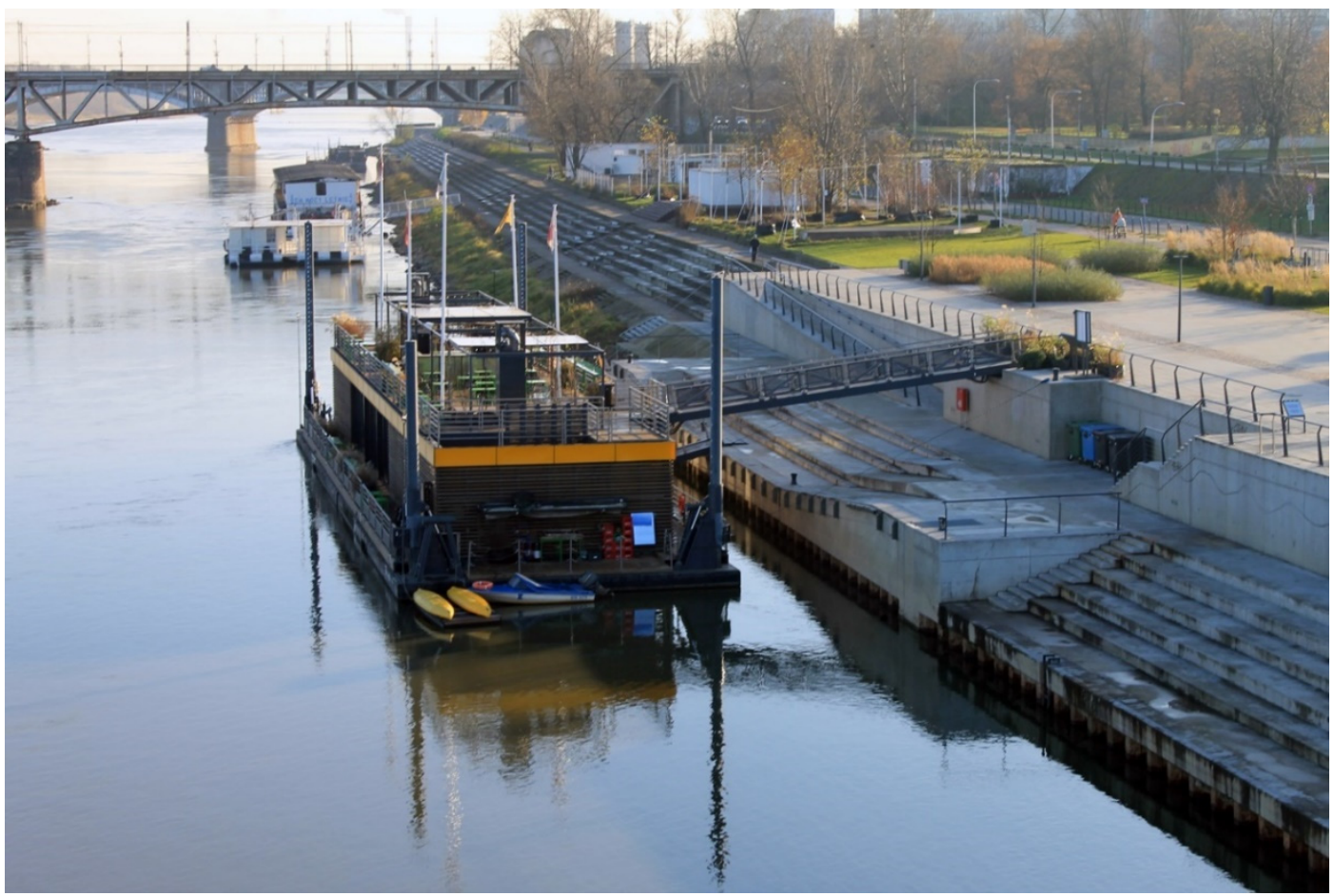

Figure 9. Water Tram Terminal during low water level $(61 \mathrm{~cm})$ on 3 March 2019 (Source: photo taken by Łukasz Piatek in December 2019).

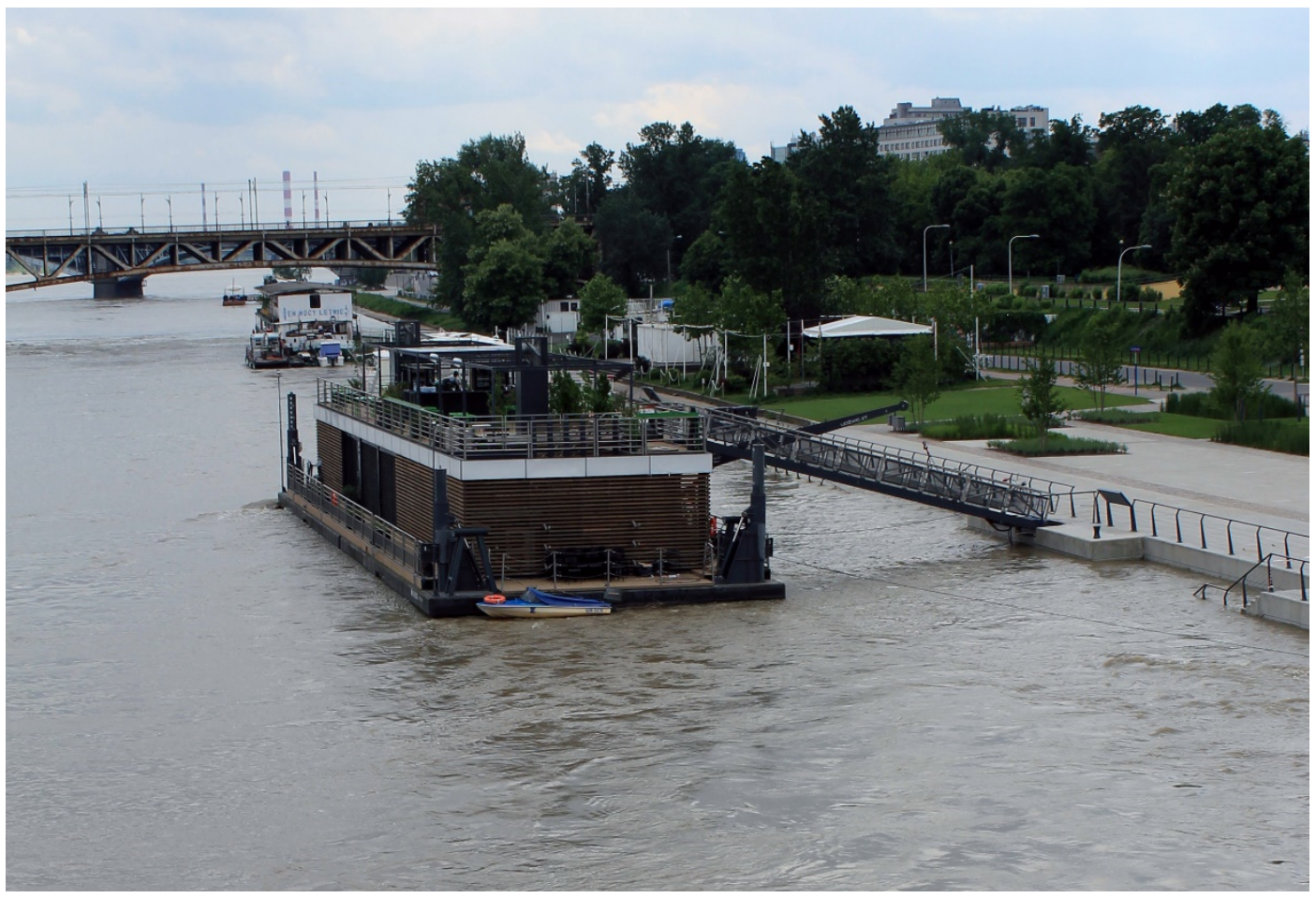

Figure 10. Water Tram Terminal during high water level $(520 \mathrm{~cm})$ on 28 May 2019 (Source: photo taken by Łukasz Piątek in May 2019). 
To meet these requirements, a special and complex mooring system consisting of winches with steel cables and custom $12 \mathrm{~m}$-long stopping piles has been designed (Stopping pile is a steel column with a cone-shaped end. It is placed in a pivoting guide in a deck-mounted base. When the floating structure is underway, the piles are hydraulically lifted and folded into a horizontal position. To hold the building in place, the piles are set vertically and lowered down to let their ends drive into the river bottom using their own weight. Then the structure can slide along them as along the typical dolphin piles). To accommodate water level changes, the buildings are located $4 \mathrm{~m}$ away from the wharf and access to them is planned through long gangways that can be attached to the main floor as well as to the roof terrace. Operation during very low water levels were predicted as well. The hull was designed to bear loads of grounding, so the $0.6 \mathrm{~m}$-draft structure can sit safely on the river bottom. Unfortunately, operating this mooring and access equipment requires a professional crew to watch the facility, which implies additional operating costs in comparison to other cases.

Assessment: The concept of placing the water tram infrastructure as well as a restaurant on the floating pontoon proved to be both very attractive to the public and flood safe. In the spring of 2019, the Floating Terminals experienced a relatively high water level close to the warning level and worked well. The main drawback of the structure (but not the floating construction in general) is a complicated mooring system and the lack of ice resistance.

\section{Results-Comparison of Different Amphibious Techniques}

The buildings studied in this paper are not very different in their appearance, size, function, or time of construction. They are all results of architectural competitions and were financed by the Warsaw municipality. At the same time, they present the diversity in the implemented flood-resilient techniques, therefore, they form an interesting material for a comparison study. Selected features of the examined buildings are shown in Table 2 .

\subsection{Flood Resilience}

The problem of quantitative flood-resilience assessment of three analyzed cases has to include the following important facts. First, over a period of 6 years since the first cases were finished, there were not enough flood events to conduct a statistically based risk analysis. Second, two buoyant cases by definition cannot be destroyed by water what is still a possible (though very unlikely) scenario for the pile building, so describing the risk of flood damage according to the water level referred to the floor cannot be implemented here. Third, the cases are not comparable in terms of their distance from the water body at its average stage (both in the vertical and horizontal direction). Therefore, during the same flood event, they are being inundated at very different water levels. Fourth, while two of them need only some flood preparation works, the third (floating terminal) requires a substantial effort to relocate the whole object in case of flooding.

This problem is illustrated in Figure 11. During low stages of water $(55 \mathrm{~cm}$ at the gauging station Warszawa Bulwary), the amphibious pavilion sits on its spot on the boulevard, the floating terminal floats on very shallow water and is accessible from the lower terrace and the pile building on the beach is not inundated. All structures are fully operational (Figure 11, pt. 1). This situation does not change much as long as rising water reaches the warning stage $(600 \mathrm{~cm})$. Up to this point, all structures can be used freely and only the floating terminal requires the crew to move the access bridge up to the higher terrace. On the east riverbank, water starts to approach the pavilion. The stage of $600 \mathrm{~cm}$ is the operational limit for two buoyant structures (Figure 11. pt. 2). Beyond this level, the boulevard covers with water and has to be closed for the public, therefore, the amphibious and floating structures need to be closed and its service connections disconnected. With the water level reaching to up $780 \mathrm{~cm}$ (20-year flood), the amphibious pavilion floats over the inundated boulevard secured in place with four dolphin piles. Floating Terminal has to be moved to the safe harbor as the stopping piles are too short to reach the riverbed and the mooring facilities on the quay are inundated (this operation of water transport to the lock in the Port of Żerań made by river tugs is possible only for a limited 
range of water height due to the clearance of bridges reducing with the rising water). The elevated building experiences flooding the piles, yet it remains its operational capacity (Figure 11 pt. 3) as it can be accessed from the street. During the extremely high flood $(950 \mathrm{~cm})$, water reaches the flood barriers at both banks. The amphibious building has to be disassembled as the dolphin piles are too short to hold it on its way up (this operation should be considered equal to the flood damage as its cost would probably exceed the building value). The floodwater reaches the usable story of the Beach Pavilion and flood damage starts here as well (Figure 11 pt. 4).

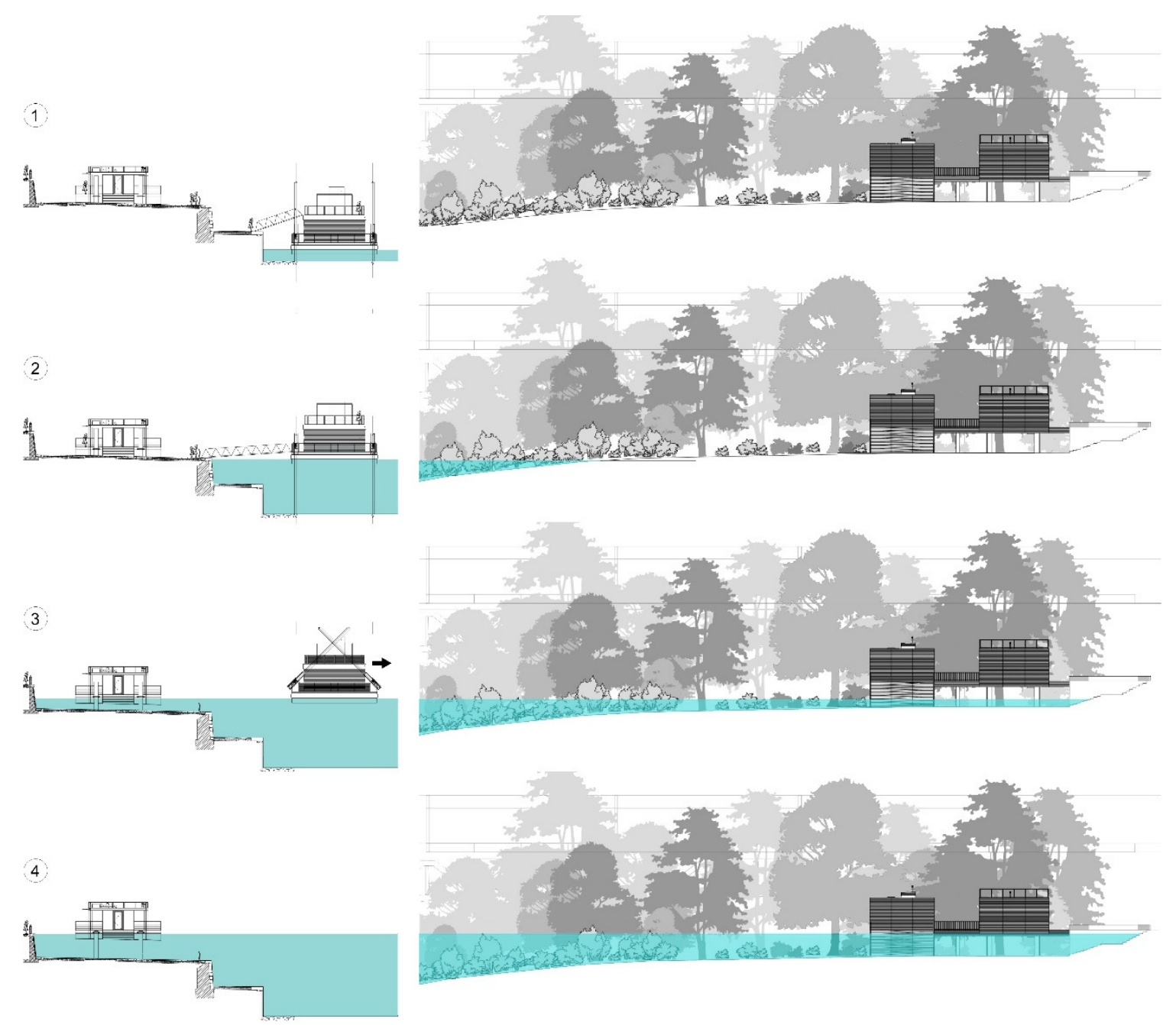

Figure 11. The flood-performance comparison of three flood resilient strategies in the context of Warsaw riverbanks (from left to right): amphibious pavilion, floating terminal, and elevated beach pavilion during different water levels: (1) low water $(55 \mathrm{~cm})$, (2) high water (600 cm-warning stage), (3) 20-year flood $(780 \mathrm{~cm})$, and (4) extremely high flood $(950 \mathrm{~cm}$, water reaches the flood barrier). All water levels referring to gauging station Warszawa Bulwary (Source: processed by the authors).

\subsection{Relation to Water vs. Relation to Land}

Besides the flood resilience, another important aspect of the analysis in terms of the usability of the examined cases is their land and water access. Being the waterfront public buildings, they need to be accessible (also for people with disabilities) from both environments. As shown in Table 2 and Figure 11, the cases differ significantly in approaching this problem which seems to be very difficult to be solved in a satisfying way for both types of access. The most convenient land access was designed in the pile building-thanks to its elevation, it can be visited easily even during a moderate flood. For the floating terminal, moving up and down with water level, land access is not comfortable, 
especially for wheelchairs, and requires constant supervision by the crew. Access from the water (and, also important, visual contact to water) is the opposite issue. While for the pile building, water is a distant and hardly experienced element, in the case of the floating terminal this relation is very close, both in terms of physical and visual contact with water. It provides comfortable and safe mooring for several vessels and offers unobstructed views of the Vistula river. The amphibious building seems to be a compromise between the other two cases: without the possibility for mooring, it can be located close enough to provide visual contact with water and to be seen from the river.

\subsection{Design Considerations}

Other aspects of the comparison, like legal, structural, organizing, and cost issues, were assessed in a qualitative way and summarized as design considerations, as they may be useful for policymakers and designers of public objects in similar settings. In this perspective, the issue of buoyancy status becomes crucial: designing a buoyant structure requires a different design process (including the weight calculations, water-resistance, and stability analysis) with different specialists involved then the more traditional reinforced concrete structure on piles. This will rather increase the costs and the time of the design process. The legal status of the object is another factor. For instance, despite their buoyancy and structure very similar to floating terminals, the amphibious pavilions are considered to be buildings due to their location on the land lots (not on the land covered with water). This implies different building codes to be followed and different insurance and financing schemes available than in the case of the floating structure.

\section{Discussion}

It has to be noted that not all of the studied solutions have been verified in practice until today. Since the opening of the Amphibious Pavilions in 2017, the river has not entered the terrace of the new boulevard and consequently, contrary to floating terminals, these structures have never confirmed their capacity to float safely. One of the directions of future research should include testing this capacity as well as examining the influence of the velocity of floodwater current on the amphibious structure in both prefloating and floating conditions.

Another issue to be elaborated on is the ecological impact. Although the presented solutions for the urbanization of the seminatural riverbanks of the Vistula in Warsaw do not seem to be extensive interventions in the landscape, the mutual effect of the impact of many small objects along the riverbanks could contribute to the significant degradation of the natural environment [69]. Therefore, future research should attempt to determine how many facilities of this kind are acceptable on the waterfront, so as not to disturb the natural functioning of the Natura 2000 area and to identify the elements that pose a risk of landscape degradation and disruption of the river's life cycle.

Conducting similar comparative studies in other cities with large flood-prone downtown areas would be a very interesting way of triangulation of the research results of this paper. A special focus should be given to the amphibious structures as they are both the least studied and the most promising flood-resilient solutions, capable of joining two opposite design problems, i.e., proximity of water and flood safety.

\section{Conclusions}

The paper gives an insight into the evolving trend of flood-resilient architecture, modern flood-resilient developments that respect the natural environment by adapting to changing water levels, considering that Warsaw, Poland, has never been a river-oriented city with a tradition of living with the water. As we have shown, international forms of environment protection to the seminatural river (Natura 2000) and retardation in the development of the boulevards (due to historical perturbations) ensured the space for river, which Western European countries are now striving for [39,40]. In addition, in terms of technical and socioeconomic aspects, the philosophy of resilience is realized $[26,28,30]$. 
Results show that the pile building has the largest margin for safe operation-it may be used despite the water level, even during seasonal flooding. However, this goes with the drawback of a poor relationship with water. In the very unlikely situation of an extreme flood that exceeds the level of $910 \mathrm{~cm}$, when the structure will be flood damaged.

Floating terminals in Warsaw, a model example of the new trend in the catering and water tourism industry in Poland [70], turned out to work more like a vessel than the building. They are the only mobile structures in the study. In Warsaw, the floating concept seems to be exploited to its limits: due to very high water level variations, land access to the terminals is limited, especially during very low and very high waters. On the cost of very complicated operation and maintenance, they complement the infrastructure of the boulevards where other flood-resilient strategies were impossible to implement.

Amphibious pavilions seem to be very interesting cases in the comparison. Their safety limit is set only by the height of the dolphin piles-in this case, on the level around $910 \mathrm{~cm}$ (similar to the floor level in the Beach Pavilion). They can operate as long as the boulevard is not flooded and provide quite good visual contact with the river. Nevertheless, this solution was never verified in the real-life context, and there are numerous doubts about its performance during the flood event.

The showcased examples are one of the first public flood resilient buildings in Poland, so, as prototypes, they might have some disadvantages. Nevertheless, these structures capable of resisting a rapid inundation as well as staying functional during low water levels are all unique local examples of "living with water" planning and design approach. It is important to note the openness of local municipality to the amphibious design paradigm of living with the river cycle. Especially when considering the number and size of amphibious pavilions built in Warsaw, the scale of the flood-resilient development is unprecedented.

Author Contributions: Conceptualization, Ł.P. and M.W.-H. methodology, Ł.P. and M.W.-H.; validation, Ł.P. and M.W.-H.; formal analysis, Ł.P. and M.W.-H.; writing-original draft preparation, M.W.-H. writing-review and editing, Ł.P.; supervision, Ł.P. and M.W.-H. Both authors have read and agreed to the published version of the manuscript.

Funding: This research received no external funding.

Acknowledgments: We would like to thank architects and designers from the studios: Artchitecture, BP Szumielewicz i Pawłowski, Navicentrum, Ponadto Grupa Projektowa, Pro Arte 11, RS Architektura Krajobrazu, and Water Home for help with preparing this paper.

Conflicts of Interest: The authors declare no conflict of interest.

\section{References}

1. Outreville, J.F. The Meaning of Risk. In Theory and Practice of Insurance; Springer: Boston, MA, USA, 1998; pp. 1-12. [CrossRef]

2. Berg-Beckhoff, G.; Wiedemann, P.; Ádám, B.; Schüz, J.; Breum Ølgaard, K.; Tanggaard Andersen, P.; Ndugwa Kabwama, S.; Nielsen, J. Risk Definitions-Risk Research Is Done in Multiple Disciplines; but Is It Multidisciplinary? Eur. J. Public Health 2015, 25 (Suppl. 3). [CrossRef]

3. Albris, K.; Lauta, K.C.; Raju, E. Disaster Knowledge Gaps: Exploring the Interface between Science and Policy for Disaster Risk Reduction in Europe. Int. J. Disaster Risk Sci. 2020, 11, 1-12. [CrossRef]

4. Kelman, I. Lost for Words amongst Disaster Risk Science Vocabulary? Int. J. Disaster Risk Sci. 2018, 9, $281-291$. [CrossRef]

5. Contreras, M.E.M. Ian Burton, W. Kates y Gilbert F. White. The environment as hazard. Nueva York: Oxford University Press, 1978. 240p. Estud. Demogr. Urbanos 1986, 1, 317. [CrossRef]

6. Hewitt, K. Regions of Risk: A Geographical Introduction to Disasters; Routledge: Abingdon, UK, 2014. [CrossRef]

7. Watts, M.J.; Bohle, H.G. The Space of Vulnerability: The Causal Structure of Hunger and Famine. Prog. Hum. Geogr. 1993, 17, 43-67. [CrossRef]

8. White, G.F.; Kates, R.W.; Burton, I. Knowing Better and Losing Even More: The Use of Knowledge in Hazards Management. Environ. Hazards 2001, 3, 81-92. [CrossRef]

9. Fekete, A.; Hufschmidt, G.; Kruse, S. Benefits and Challenges of Resilience and Vulnerability for Disaster Risk Management. Int. J. Disaster Risk Sci. 2014, 5, 3-20. [CrossRef] 
10. Oliver-Smith, A.; Hoffman, S. Peru's Five-Hundred-Year Earthquake: Vulnerability in Historical Context. Angry Earth Disaster Anthropol. Perspect. 2020, 83-93. [CrossRef]

11. Ruggieri, S.; Perrone, D.; Leone, M.; Uva, G.; Aiello, M.A. A Prioritization RVS Methodology for the Seismic Risk Assessment of RC School Buildings. Int. J. Disaster Risk Reduct. 2020, 51, 101807. [CrossRef]

12. Upton, C. Mapping Vulnerability: Disasters, Development and People Edited by Greg Bankoff, Georg Frerks and Dorothea Hilhorst. Geogr. J. 2006, 172, 172-173. [CrossRef]

13. Kodur, V.; Kumar, P.; Rafi, M.M. Fire Hazard in Buildings: Review, Assessment and Strategies for Improving Fire Safety. PSU Res. Rev. 2019, 4, 1-23. [CrossRef]

14. Wojnowska-Heciak, M.; Grzebulska, B.; Suchocka, M.; Warmińska, M. Use of Structural Soil as a Method for Increasing Flood Resilience in Praga Północ in Warsaw. Ann. Wars. Univ. Life Sci. SGGW Hortic. Landsc. Arch. 2020, 40, 15-28. [CrossRef]

15. Hossain, M.K.; Meng, Q. A Fine-Scale Spatial Analytics of the Assessment and Mapping of Buildings and Population at Different Risk Levels of Urban Flood. Land Use Policy 2020, 99, 104829. [CrossRef]

16. De Bruijn, K.M.; Klijn, F. Risky Places in the Netherlands: A First Approximation for Floods. J. Flood Risk Manag. 2009, 2, 58-67. [CrossRef]

17. Pearson, J.; Punzo, G.; Mayfield, M.; Brighty, G.; Parsons, A.; Collins, P.; Jeavons, S.; Tagg, A. Flood Resilience: Consolidating Knowledge between and within Critical Infrastructure Sectors. Environ. Syst. Decis. 2018, 38, 318-329. [CrossRef]

18. Resilience: International Policies, Practices and Discourses. Resilience 2016, 4, ebi. [CrossRef]

19. Scottish Environment Production Agency. Technical Flood Risk Guidance for Stakeholders (Reference: SS-NFR-P-002); SEPA: Stirling, UK, 2015.

20. Dinh, Q.; Balica, S.; Popescu, I.; Jonoski, A. Climate Change Impact on Flood Hazard, Vulnerability and Risk of the Long Xuyen Quadrangle in the Mekong Delta. Int. J. River Basin Manag. 2012, 10, 103-120. [CrossRef]

21. Takeuchi, K.; Chavoshian, A.; Simonovic, S.P. Floods: From Risk to Opportunity. J. Flood Risk Manag. 2018, 11, e12046. [CrossRef]

22. Fischbach, J. Reducing Future Flood Damage in New Orleans through Home Elevation and Land Use Changes. 2011. Available online: https://www.rand.org/pubs/research_briefs/RB9612.html (accessed on 20 November 2020).

23. Florin, M.V.; Linkov, I. IRGC Resource Guide on Resilience; EPFL International Risk Governance Center: Lausanne, Switzerland, 2016.

24. Nie, L. Enhancing Urban Flood Resilience-A Case Study for Policy Implementation. Proc. Inst. Civ. Eng. Water Manag. 2016, 169, 85-93. [CrossRef]

25. GAR. The 2015 Global Assessment Report on Disaster Risk Reduction; United Nations International Strategy for Disaster Reduction: Geneva, Switzerland, 2019. [CrossRef]

26. Golz, S.; Schinke, R.; Naumann, T. Assessing the Effects of Flood Resilience Technologies on Building Scale. Urban Water J. 2015, 12, 30-43. [CrossRef]

27. Balasbaneh, A.T.; Bin Marsono, A.K.; Gohari, A. Sustainable Materials Selection Based on Flood Damage Assessment for a Building Using LCA and LCC. J. Clean. Prod. 2019, 222, 844-855. [CrossRef]

28. Dawson, R.; Ball, T.; Werritty, J.; Hall, J.W.; Roche, N. Assessing the Effectiveness of Non-Structural Flood Management Measures in the Thames Estuary under Conditions of Socio-Economic and Environmental Change. Glob. Environ. Chang. 2011, 21, 626-646. [CrossRef]

29. Bubeck, P.; Kreibich, H.; Penning-Rowsell, E.C.; Botzen, W.J.W.; de Moel, H.; Klijn, F. Explaining Differences in Flood Management Approaches in Europe and in the USA-A Comparative Analysis. J. Flood Risk Manag. 2017, 10, 436-445. [CrossRef]

30. Bachner, G.; Bednar-Friedl, B. The Effects of Climate Change Impacts on Public Budgets and Implications of Fiscal Counterbalancing Instruments. Environ. Model. Assess. 2019, 24, 121-142. [CrossRef]

31. Hammond, M.J.; Chen, A.S.; Djordjević, S.; Butler, D.; Mark, O. Urban Flood Impact Assessment: A State-of-the-Art Review. Urban Water J. 2015, 12, 14-29. [CrossRef]

32. Zevenbergen, C. Flood Resilience; Florin, M.-V., Linkov, I., Eds.; International Riks Governance Council (IRGC): Lausanne, Switzerland, 2016.

33. Letcher, T.M. Climate Change; Elsevier: Amsterdam, The Netherlands, 2015. 
34. Hall, J.; Arheimer, B.; Aronica, G.T.; Bilibashi, A.; Boháč, M.; Bonacci, O.; Borga, M.; Burlando, P.; Castellarin, A.; Chirico, G.B. A European Flood Database: Facilitating Comprehensive Flood Research beyond Administrative Boundaries. Proc. Int. Assoc. Hydrol. Sci. 2015, 370, 89-95. [CrossRef]

35. Sassi, M.; Nicotina, L.; Pall, P.; Stone, D.; Hilberts, A.; Wehner, M.; Jewson, S. Impact of Climate Change on European Winter and Summer Flood Losses. Adv. Water Resour. 2019, 129, 165-177. [CrossRef]

36. Rojas, R.; Feyen, L.; Watkiss, P. Climate Change and River Floods in the European Union: Socio-Economic Consequences and the Costs and Benefits of Adaptation. Glob. Environ. Chang. 2013, 23, 1737-1751. [CrossRef]

37. Kundzewicz, Z. Changes in Flood Risk in Europe; International ASSN of Hydrological Sciences: Wallingford, UK, 2012.

38. Blöschl, G.; Hall, J.; Parajka, J.; Perdigão, R.A.P.; Merz, B.; Arheimer, B.; Aronica, G.T.; Bilibashi, A.; Bonacci, O.; Borga, M. Changing Climate Shifts Timing of European Floods. Science 2017, 357, 588-590. [CrossRef]

39. Blöschl, G.; Hall, J.; Viglione, A.; Perdigão, R.A.P.; Parajka, J.; Merz, B.; Lun, D.; Arheimer, B.; Aronica, G.T.; Bilibashi, A. Changing Climate Both Increases and Decreases European River Floods. Nature 2019, 573, 108-111. [CrossRef]

40. Room for the River Programme|Dutch Water Sector. Available online: https://www.dutchwatersector.com/ news/room-for-the-river-programme (accessed on 4 October 2020).

41. SW12: Making Space for Water. Available online: https://www.gov.uk/countryside-stewardship-grants/ making-space-for-water-sw12 (accessed on 4 October 2020).

42. Vermaat, J.E.; Wagtendonk, A.J.; Brouwer, R.; Sheremet, O.; Ansink, E.; Brockhoff, T.; Plug, M.; Hellsten, S.; Aroviita, J.; Tylec, L. Assessing the Societal Benefits of River Restoration Using the Ecosystem Services Approach. Hydrobiologia 2016, 769, 121-135. [CrossRef]

43. Almeroth-Williams, T. How to Build a Flood Resilient Future. 2020. Available online: https://www.greenbiz. com/article/how-build-flood-resilient-future (accessed on 20 November 2020).

44. English, E.; Klink, N.; Turner, S. Thriving with water: Developments in amphibious architecture in North America. In Proceedings of the 3rd European Conference on Flood Risk Management (FLOODrisk 2016), Lyon, France, 17-21 October 2016; Volume 7. [CrossRef]

45. Aleksić, J.; Kosanović, S.; Tomanović, D.; Grbić, M.; Murgul, V. Housing and Climate Change-Related Disasters: A Study on Architectural Typology and Practice. Procedia Eng. 2016, 165, 869-875. [CrossRef]

46. Barker, R.; Coutts, R. Aquatecture: Buildings and Cities Designed to Live and Work with Water; RIBA Publishing: London, UK, 2015.

47. Nillesen, A.L.; Singelenberg, J. Amphibious Housing in the Netherlands. Architecture and Urbanism on the Water; NAI: Rotterdam, The Netherlands, 2011.

48. Lenzholzer, S.; Duchart, I.; van den Brink, A. The Relationship between Research and Design. In Research in Landscape Architecture. Methods and Methodology; den Brink, A., van Bruns, D., Tobi, H., Bell, S., Eds.; Routledge: Abingdon, UK, 2017; pp. 54-55.

49. Groat, L.N. Architectural Research Methods; John Wiley \& Sons: Hoboken, NJ, USA, 2013.

50. Flyvbjerg, B. Five Misunderstandings about Case-Study Research. Qual. Inq. 2006, 12, 219-245. [CrossRef]

51. van den Brink, A.; Bruns, D.; Tobi, H.; Bell, S. Research in Landscape Architecture. Methods and Methodology; Routledge: Abingdon, UK, 2016; pp. 105-119.

52. Prominski, M.; Stokman, A.; Stimberg, D.; Voermanek, H.; Zeller, S. River. Space. Design: Planning Strategies, Methods and Projects for Urban Rivers; Walter de Gruyter: Boston, MA, USA, 2012.

53. Dojlido, J.R. Water Quality in the Vistula Basin: A River under Stress. In River Quality Dynamics and Restoration; Talyor \& Francis Group: Milton Park, UK, 1997; pp. 77-87. [CrossRef]

54. de Waal, L.C.; Large, A.R.G.; Gippel, C.J.; Wade, P.M. River and Floodplain Rehabilitation in Western Europe: Opportunities and Constraints. River Syst. 1996, 9, 679-693. [CrossRef]

55. Gerner, N.V.; Nafo, I.; Winking, C.; Wencki, K.; Strehl, C.; Wortberg, T.; Niemann, A.; Anzaldua, G.; Lago, M.; Birk, S. Large-Scale River Restoration Pays off: A Case Study of Ecosystem Service Valuation for the Emscher Restoration Generation Project. Ecosyst. Ser. 2018, 30, 327-338. [CrossRef]

56. Wasilewicz, M. Wisła w Warszawie. 2013. Available online: www.klimatwoda.pl (accessed on 4 October 2018).

57. Warsaw Schwarzplan. Available online: https://schwarzplan.eu (accessed on 2 November 2020).

58. Janczewski, H. Warszawa Geneza i Rozwój Inżynierii Miejskiej; Arkady: Warsaw, Poland, 1971. 
59. Fal, B.; Dabrowski, P. Dwieście Lat Obserwacji i Pomiarów Hydrologicznych Wisły w Warszawie. Gospod. Wodna 2001, 12, 503-510.

60. Gutry-Korycka, M. Wielkie Wody Wisły Środkowej w Ujęciu Historycznym. Prace Studia Geogr. 2007, 38, 85-103.

61. Fal, B.; Dabrowski, P. Dwieście Lat Obserwacji i Pomiarów Hydrologicznych Wisły w Warszawie. Gospod. Wodna 2001, 11, 461-467.

62. Grela, J.; Słota, H.; Zieliński, J. Dorzecze Wisły. Monografia Powodzi Lipiec 1997; IMGW: Warsaw, Poland, 1999.

63. Cyberski, J.; Grześ, M.; Gutry-Korycka, M.; Nachlik, E.; Kundzewicz, Z. History of Floods on the River Vistula. Hydrol. Sci. J. 2006, 51, 799-817. [CrossRef]

64. World Wide Fund for Nature. Rzeki Dla Życia-Wisła; WWF: Gland, Switzerland, 2008.

65. Kwasiborska, W. Architektura Warszawy. Pawilon Plażowy Nad Wisłą-Mamy Najnowsze Zdjęcia z Placu Budowy. Arch. Murator Plus 2013. Available online: https://archirama.muratorplus.pl/architektura/ architektura-warszawy-pawilon-plazowy-nad-wisla-mamy-najnowsze-zdjecia-z-placu-budowy,67_2802. html (accessed on 20 November 2020).

66. Pawilon Plażowy. Available online: http://ponadto.com/pawilon-plazowy-nad-wisla (accessed on 11 June 2019).

67. Projekt Architektoniczno-Budowlany-Pawilon Typ A-Informacja Turystyczna z Toaleta Publiczna i Częścia Gastronomiczna; BPSP: Warsaw, Poland, 2012.

68. Projekt Budowlano-Wykonawczy Obiektu Pływajacego "Przystań" Zacumowanego Do Lewobrzeżnego Bulwaru Wisły; BPSP: Warsaw, Poland, 2012.

69. Wojnowska-Heciak, M. The Naturalness of the Vistula Riverbank's Landscape: Warsaw Inhabitants' Perceptions. Sustainability 2019, 11, 5957. [CrossRef]

70. Piatek, Ł.; Wycisk, A.A.; Parzych, D.; Modrzejewska, K. Floating buildings in the hotel, catering and water tourism industry in Poland Business environment survey. J. Water Land Dev. 2020, 45, 100-106. [CrossRef]

Publisher's Note: MDPI stays neutral with regard to jurisdictional claims in published maps and institutional affiliations.

(C) 2020 by the authors. Licensee MDPI, Basel, Switzerland. This article is an open access article distributed under the terms and conditions of the Creative Commons Attribution (CC BY) license (http://creativecommons.org/licenses/by/4.0/). 